\title{
DNA elimination in embryogenic development of Pennisetum glaucum x Pennisetum purpureum (Poaceae) hybrids
}

\author{
J.D. Nunes ${ }^{1}$, A.L.S. Azevedo ${ }^{1}$, A.V. Pereira ${ }^{1}$, C.M.P. Paula ${ }^{2}$, J.M.S. Campos ${ }^{3}$, \\ F.J.S. Lédo ${ }^{1}$ and V.B. Santos ${ }^{4}$ \\ ${ }^{1}$ Empresa Brasileira de Pesquisa Agropecuária, Juiz de Fora, MG, Brasil \\ ${ }^{2}$ Laboratório de Citogenética, Departamento de Biologia, \\ Universidade Federal de Lavras, Lavras, MG, Brasil \\ ${ }^{3}$ Laboratório de Genética e Biotecnologia, Departamento de Biologia, \\ Instituto de Ciências Biológicas, Universidade Federal de Juiz de Fora, \\ Juiz de Fora, MG, Brasil \\ ${ }^{4}$ Universidade Federal do Acre, Rio Branco, AC, Brasil \\ Corresponding author: A.L.S. Azevedo \\ E-mail: ana.azevedo@embrapa.br
}

Genet. Mol. Res. 12 (4): 4817-4826 (2013)

Received August 28, 2013

Accepted September 9, 2013

Published October 22, 2013

DOI http://dx.doi.org/10.4238/2013.October.22.1

\begin{abstract}
Interspecific hybridization between Napier grass (Pennisetum purpureum), which is widely grown in Brazil for cattle forage, and pearl millet (Pennisetum glaucum) has been used as a breeding strategy for the development of improved cultivars. However, the hybrid between these two species is sterile due to its triploid condition $(2 \mathrm{n}=3 \mathrm{x}=21$ chromosomes), which hinders its use in crop breeding programs. It is known that genomic alterations result from the hybridization process. In order to measure the loss of DNA during embryo development, we used flow cytometry to estimate the nuclear DNA content of triploid and tetraploid embryos produced by interspecific hybridization between Napier grass and pearl millet. The triploid and tetraploid hybrids had a mean DNA content of 4.99-4.87
\end{abstract}


and 5.25-4.84 pg, at 10 and 30 days after pollination, respectively. The mean reduction in DNA content was higher in the tetraploid hybrids. The flow cytometry results revealed progressive genomic instability in these triploid and tetraploid hybrids, with this instability causing significant alterations in the DNA content of the hybrids.

Key words: Elephant grass; Flow cytometry; Grasses; Hybridization

\section{INTRODUCTION}

The Poaceae family comprises a large number of cultivated species of high economic value, such as corn, rice, wheat, rye, and various forage grasses. More than 10,000 of all cultivated plant species belong to the Poaceae family, which together comprise approximately $60 \%$ of the world's food production (Keller and Feuillet, 2000).

Pennisetum is one of the most important genera of the Poaceae family. The genus comprises approximately 140 species (Brunken, 1977). Pennisetum glaucum (L.) R. Br. (pearl millet) and Pennisetum purpureum Schumach (Napier grass) are the most important species economically, which are widely used as forage grasses. Pearl millet's ability to produce grains under conditions of drought, heat, and in infertile soils, along with its high dry matter yield has contributed to the successful cultivation of this species (Pereira et al., 2001; O'Kennedy et al., 2004). Napier grass is known for its high productive potential, nutritional quality, good palatability, and perennial nature (Pereira et al., 2001).

Interspecific hybridization between Napier grass $(2 n=4 x=28$ chromosomes $)$ and pearl millet $(2 \mathrm{n}=2 \mathrm{x}=14$ chromosomes) has been used as a genetic breeding strategy for the development of cultivars that combine the desired characteristics of the two species. However, the resulting hybrid is sterile due to the triploid condition $(2 \mathrm{n}=3 \mathrm{x}=21$ chromosomes), a fact that impairs its use in breeding programs. The fertility of these hybrids can be restored by chromosome duplication with the use of colchicine (Abreu et al., 2006; Barbosa et al., 2007; Campos et al., 2009a,b), but this method has low efficiency, and the DNA duplication cannot be achieved at large scales.

The combination of different species' genomes within the cellular and nuclear environment of one parent can lead to the expression of various types of intergenomic conflict, including nucleo-cytoplasmic incompatibility (Jones and Pasakinskiené, 2005), and can induce the elimination of DNA sequences. These conflicts arise due to differences in genome size, genome composition, regulatory mechanisms, cell cycle duration, and genetic or epigenetic modifications (Jones and Hegarty, 2009). Feldman et al. (1997) identified a rapid and reproducible loss of low-copy DNA sequences from hybrid genomes in Triticum aestivum. Campos (2007) demonstrated that the frequency of micronuclei, an alteration related to DNA sequence elimination, significantly increased between 10 and 25 days after pollination (DAP) in triploid Pennisetum embryos. More detailed knowledge about this sequence elimination, besides helping to clarify the mechanisms of DNA elimination generally, could be used to select stable genotypes for breeding programs. Therefore, the objective of the present study was to estimate the nuclear DNA content of embryos after interspecific hybridization in order to evaluate the occurrence of DNA sequence eliminations during embryo development. 


\section{MATERIAL AND METHODS}

\section{Plant materials}

Crosses between pearl millet and Napier grass were performed between April and July of 2009 and 2010 to obtain the F1 hybrids (triploid and tetraploid). The experiments were carried out at the Embrapa Dairy Cattle experimental station, in Coronel Pacheco, MG, Brazil. Fifteen interspecific crosses were performed between genotypes from the Embrapa Napier Grass Active Germplasm Bank (male parents) and P. glaucum (female parents) (Table 1). The inflorescences were protected with a paper bag and each cross was done manually. Two inflorescences from each cross were collected at 10, 15, 20, 25, and $30 \mathrm{DAP}$, corresponding to 10 inflorescences per cross.

Table 1. Parental genotypes used in the crosses and the triploid and tetraploid interspecific F1 hybrids.

\begin{tabular}{lcr}
\hline Male parent (ploidy level) & Female parent (ploidy level) & F1 hybrid (ploidy level) \\
\hline BAG 1 (4X) & M 10 (2X) & $1(3 \mathrm{X})$ \\
BAG 19 (4X) & M 3 (2X) & $2(3 \mathrm{X})$ \\
BAG 27 (4X) & M 9 (2X) & $3(3 \mathrm{X})$ \\
BAG 30 (4X) & M 5 (2X) & $4(3 \mathrm{X})$ \\
BAG 75 (4X) & M 1 (2X) & $5(3 \mathrm{X})$ \\
BAG 96-27-3 (4X) & M 31 (2X) & $6(3 \mathrm{X})$ \\
BAG 92-37-5 (4X) & M 59 (2X) & $7(3 \mathrm{X})$ \\
'Pioneiro'(4X) & M 11 (2X) & $8(3 \mathrm{X})$ \\
'Pioneiro'(4X) & M 6 (2X) & $9(3 \mathrm{X})$ \\
'Mineiro' (4X) & M 8 (2X) & $10(3 \mathrm{X})$ \\
PCM 0701-01 (6X) & M 2 (2X) & $11(4 \mathrm{X})$ \\
PCM 0701-01 (6X) & M 7 (2X) & $12(4 X)$ \\
PCM 0701-01 (6X) & M 11 (2X) & $13(4 \mathrm{X})$ \\
PCM 0701-03 (6X) & M 4 (2X) & $14(4 X)$ \\
PCM 0701-24 (6X) & M 59 (2X) & $15(4 X)$ \\
\hline
\end{tabular}

\section{Flow cytometry analysis}

For DNA quantification and ploidy level determination of the hybrids derived from each cross, 30 embryos were excised from the seeds immediately after inflorescence collection for each of the DAPs. The DNA content of the parental genotypes was quantified in young leaves of each plant.

Ten hybrid embryos were triturated with a scalpel, together with 20-30 mg leaf tissue of Pisum sativum L. (1753) (internal reference standard containing 9.09 pg DNA), on a Petri dish containing $500 \mu \mathrm{L}$ LB01 buffer (Dolezel and Bartos, 2005). For quantification of parental DNA, young leaves of each parent were used together with $20-30 \mathrm{mg} P$. sativum leaf tissue. The nuclear suspension was aspirated through 2 layers of gauze to remove triturated tissue, filtered through a $50-\mu \mathrm{m}$ Millipore membrane, and transferred to a polystyrene tube. Next, $25 \mu \mathrm{L} 1 \mathrm{mg} / \mathrm{mL}$ propidium iodide and $25 \mu \mathrm{L} 1 \mathrm{mg} / \mathrm{mL}$ RNAse were added to the nuclear suspension. For DNA quantification, at least 10,000 nuclei per sample were analyzed in a FACSCalibur cytometer (Becton Dickinson). Histograms were obtained using the Cell Quest software and were analyzed on the WinMDI 2.9 software (http://facs.scripps.edu/software.html). The formula used for converting fluorescence values to DNA content was: DNA content $(\mathrm{pg})=[$ (sample G1 peak mean) $/$ (standard G1 peak mean)] x standard 2C DNA content (pg DNA) (Dolezel and Bartos, 2005). 
Data were analyzed as a split-plot time arrangement in a randomized block design, according to Steel et al. (1997). Analysis of variance and polynomial regressions between DAP and DNA content were conducted using the SAS GLM program (SAS, 2000).

\section{RESULTS}

The DNA content ranged from 4.45 to $5.82 \mathrm{pg}$ for triploid hybrids and from 4.41 to $4.93 \mathrm{pg}$ for tetraploid hybrids. Reductions in the amount of DNA during embryo development ranged from 4.58 to $6.07 \%$.

The DNA content of embryos was similar among most triploid hybrids throughout seed development (Figure 1A-J). The mean DNA content of embryos at 10 DAP was $4.99 \mathrm{pg}$, but showed significant reductions during embryo development with an average of $4.87 \mathrm{pg}$ at 30 DAP. Only hybrid 9 (Figure 1I) presented an inverse behavior, i.e., the DNA content was $4.76 \mathrm{pg}$ at $10 \mathrm{DAP}$ and $5.09 \mathrm{pg}$ at $30 \mathrm{DAP}$. DAP and the interaction between DAP and the cross type significantly influenced DNA elimination $(\mathrm{P}<0.05)$.

A

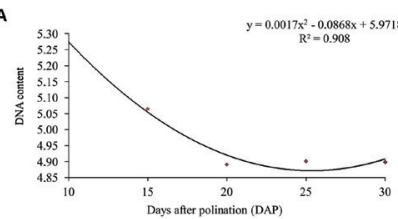

B
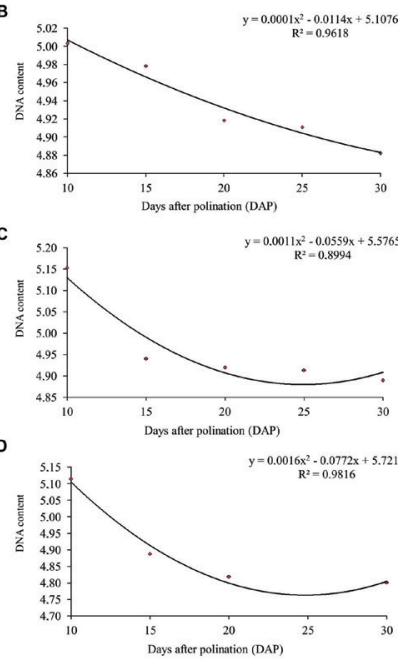

E

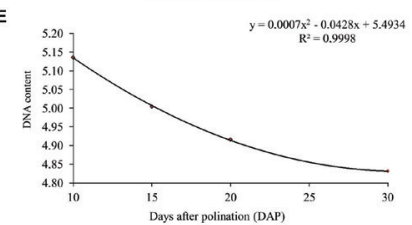

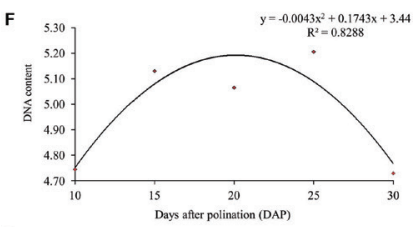

G

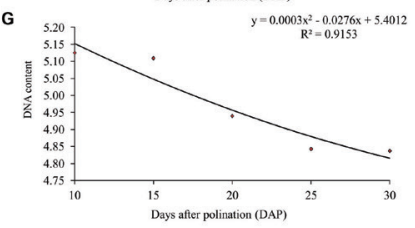

H

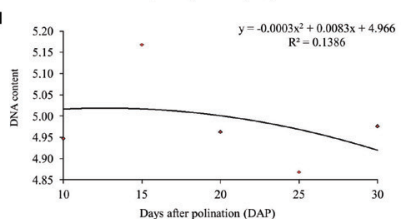

1
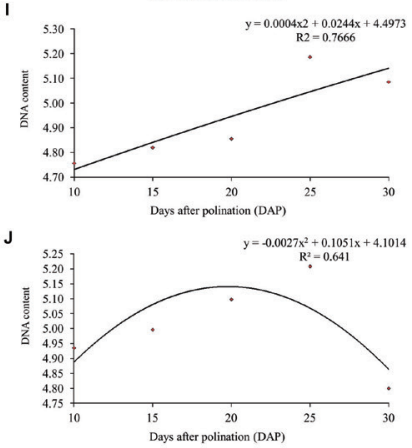

Figure 1. Regression analysis of DNA content in triploid hybrids obtained from crosses between Napier grass and pearl millet. A. Hybrid 1. B. Hybrid 2. C. Hybrid 3. D. Hybrid 4. E. Hybrid 5. F. Hybrid 6. G. Hybrid 7. H. Hybrid 8. I. Hybrid 9. J. Hybrid 10. 
Among the 10 triploid hybrids obtained, only hybrid 2 showed no significant effect of DAP on the DNA content. This finding indicates the higher stability of this hybrid. The DNA content of hybrid 2 was 5.15 and $4.89 \mathrm{pg}$ at 10 and 30 DAP, respectively.

A significant effect of DAP on DNA content was observed for all tetraploid hybrids (Figure 2A-E). The mean DNA content of tetraploid hybrids was 5.25 and $4.84 \mathrm{pg}$ at 10 and 30 DAP, respectively. Only hybrids 13 and 14 showed no indication of any reduction in DNA content during embryo development (Figure 2C and D). The mean DNA content of hybrids 13 and 14 was 4.79 and $4.55 \mathrm{pg}$ at 10 DAP and 4.93 and 4.66 at 30 DAP, respectively.

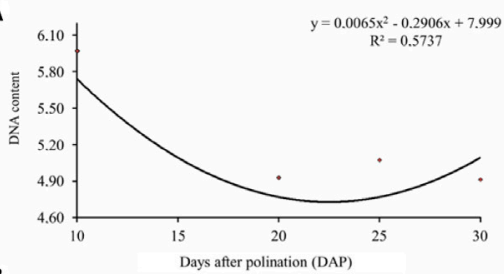

B

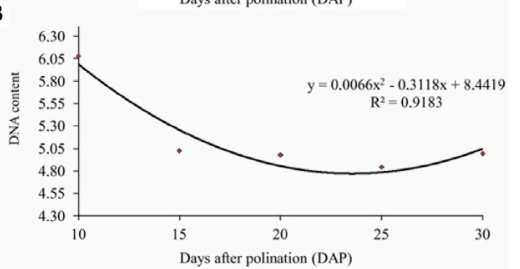

C

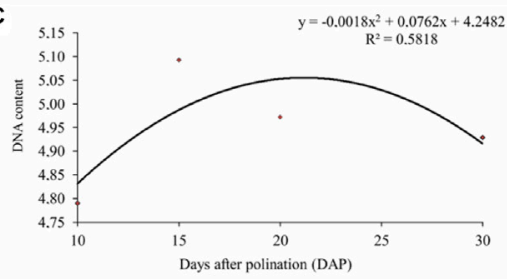

D

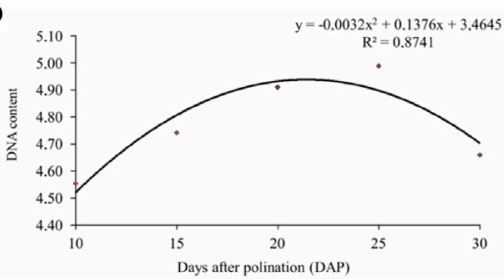

E

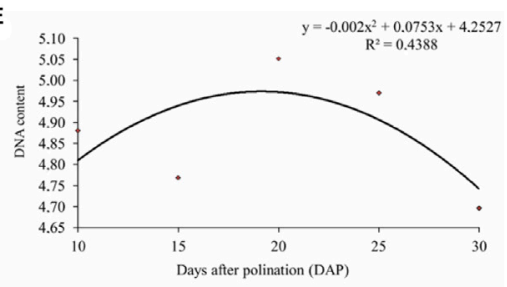

Figure 2. Regression analysis of DNA content in tetraploid hybrids obtained from crosses between hexaploid hybrids and pearl millet. A. Hybrid 11. B. Hybrid 12. C. Hybrid 13. D. Hybrid 14. E. Hybrid 15. 
The estimates of the coefficients of variation were low for triploid and tetraploid hybrids ( 1.59 and $1.31 \%$, respectively). These coefficients indicate good precision and reliability of the values obtained (Figure $3 \mathrm{~A}$ and $\mathrm{B}$ ).

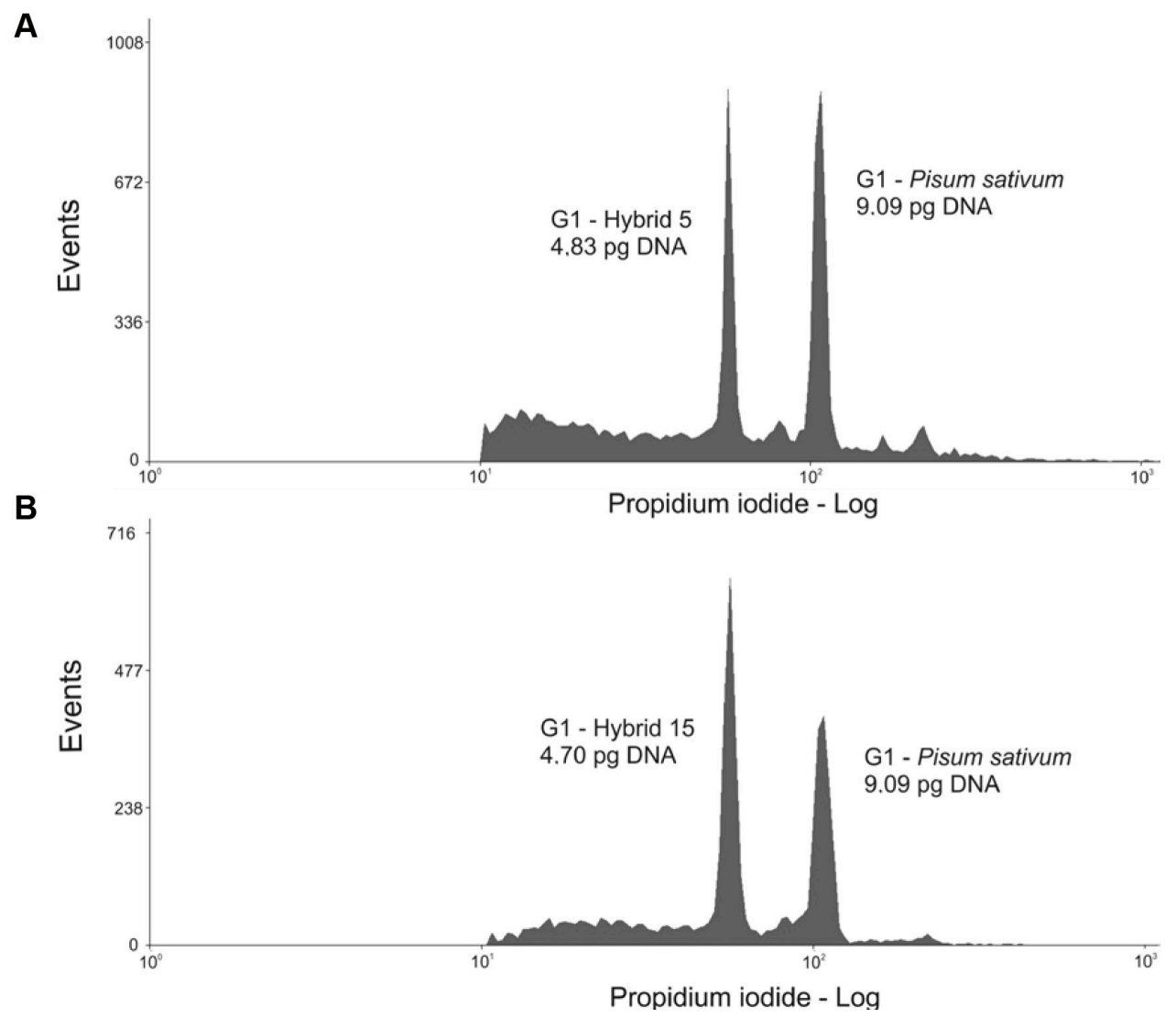

Figure 3. Flow cytometry histograms for the quantification of DNA. A. Triploid hybrid 5 (4.83 pg); B. tetraploid hybrid 15 (4.70 pg).

The DNA content of the pearl millet and Napier grass genotypes used as parents in the crosses were also obtained in order to compare the DNA content of the hybrids at 30 DAP with the DNA content expected based on the average of the parental species (Table 2).

A significant reduction was observed in DNA content when compared with the expected values (average of parental DNA contents). The DNA content of triploid hybrids at 30 DAP ranged from 4.73 to $5.09 \mathrm{pg}$. The largest reduction in DNA content was observed for hybrid 4, with a DNA elimination of $0.29 \mathrm{pg}(5.13 \%)$. Hybrids 6, 7, and 10 showed an increase relative to the parental DNA content, ranging from 2.83 to $7.62 \%$. A severe reduction in DNA content of up to $40.5 \%$, corresponding to $3.17 \mathrm{pg}$, was observed for the tetraploid hybrids at 30 DAP. 


\begin{tabular}{|c|c|c|c|c|c|}
\hline Hybrid & Parents & $\begin{array}{l}\text { Parental DNA content } \\
(\mathrm{pg})\end{array}$ & $\begin{array}{c}\text { Expected DNA content } \\
(\mathrm{pg})\end{array}$ & $\begin{array}{l}\text { Observed DNA content } \\
(\mathrm{pg})^{*}\end{array}$ & $\begin{array}{c}\text { Variation in DNA } \\
\text { content }\end{array}$ \\
\hline 1 & BAG 1 & $\begin{array}{l}5.51 \\
4.68\end{array}$ & 5.09 & 4.90 & $0.19 \mathrm{pg}(3.73 \%)$ \\
\hline 2 & $\begin{array}{l}\text { M } 10 \\
\text { BAG } 19\end{array}$ & $\begin{array}{l}4.68 \\
5.27 \\
4.67\end{array}$ & 4.97 & 4.88 & $0.09 \mathrm{pg}(1.81 \%)$ \\
\hline 3 & $\begin{array}{l}\text { M3 } \\
\text { BAG } 27 \\
\text { M } 9\end{array}$ & $\begin{array}{l}4.67 \\
5.30 \\
4.67\end{array}$ & 4.98 & 4.89 & $0.09 \mathrm{pg}(1.81 \%)$ \\
\hline 4 & $\begin{array}{l}\text { BAG } 30 \\
\text { M } 5\end{array}$ & $\begin{array}{l}5.47 \\
4.66\end{array}$ & 5.06 & 4.80 & $0.29 \mathrm{pg}(5.13 \%)$ \\
\hline 5 & $\begin{array}{l}\text { BAG } 75 \\
\text { M } 1\end{array}$ & $\begin{array}{l}5.23 \\
4.65\end{array}$ & 4.94 & 4.83 & $0.11 \mathrm{pg}(2.23 \%)$ \\
\hline 6 & $\begin{array}{l}\text { BAG 96-27-3 } \\
\text { M } 31\end{array}$ & $\begin{array}{l}4.34 \\
4.86\end{array}$ & 4.60 & 4.73 & $0.13 \mathrm{pg}(2.83 \%)$ \\
\hline 7 & $\begin{array}{l}\text { BAG 92-37-5 } \\
\text { M } 59\end{array}$ & $\begin{array}{l}4.09 \\
4.84\end{array}$ & 4.46 & 4.80 & $0.34 \mathrm{pg}(7.62 \%)$ \\
\hline 8 & $\begin{array}{l}\text { 'PIONEIRO' } \\
\text { M } 11\end{array}$ & $\begin{array}{l}5.25 \\
4.67\end{array}$ & 4.96 & 4.84 & $0.12 \mathrm{pg}(2.41 \%)$ \\
\hline 9 & $\begin{array}{l}\text { 'PIONEIRO' } \\
\text { M } 6\end{array}$ & $\begin{array}{l}5.25 \\
5.29\end{array}$ & 5.27 & 5.09 & $0.18 \mathrm{pg}(3.41 \%)$ \\
\hline 10 & $\begin{array}{l}\text { 'MINEIRO' } \\
\text { M } 8\end{array}$ & $\begin{array}{l}4.14 \\
5.06\end{array}$ & 4.60 & 4.80 & $0.20 \mathrm{pg}(4.35 \%)$ \\
\hline 11 & $\begin{array}{l}\text { PCM0701-01 } \\
\text { M } 2\end{array}$ & $\begin{array}{l}8.80 \\
4.65\end{array}$ & 6.72 & 4.91 & $1.81 \mathrm{pg}(26.93 \%)$ \\
\hline 12 & $\begin{array}{l}\text { PCM0701-01 } \\
\text { M } 7\end{array}$ & $\begin{array}{l}8.80 \\
4.67\end{array}$ & 6.73 & 4.99 & $1.74 \mathrm{pg}(25.85 \%)$ \\
\hline 13 & $\begin{array}{l}\text { PCM0701-01 } \\
\text { M } 11\end{array}$ & $\begin{array}{l}8.80 \\
4.67\end{array}$ & 6.73 & 4.93 & $1.80 \mathrm{pg}(26.75 \%)$ \\
\hline 14 & $\begin{array}{l}\text { PCM0701-03 } \\
\text { M } 4\end{array}$ & $\begin{array}{r}10.82 \\
4.84\end{array}$ & 7.83 & 4.66 & $3.17 \mathrm{pg}(40.48 \%)$ \\
\hline 15 & $\begin{array}{l}\text { PCM0701-24 } \\
\text { M } 59\end{array}$ & $\begin{array}{l}9.94 \\
4.84\end{array}$ & 7.39 & 4.70 & $2.69 \mathrm{pg}(36.40 \%)$ \\
\hline
\end{tabular}

*30 days after pollination.

\section{DISCUSSION}

According to Martel et al. (1997), the DNA contents of Napier grass and pearl millet are 4.59 and $4.71 \mathrm{pg}$, respectively. The triploid hybrid DNA content expected based on the average of the parents would therefore be approximately $4.65 \mathrm{pg}$. Campos (2007) reported a range of the DNA content of triploid Pennisetum hybrids of 4.32 to $4.60 \mathrm{pg}$ values compatible with those observed in the present study.

An immediate consequence of allopolyploid formation is the union of distinct genomes that are similar enough to permit the pairing of homeologous chromosomes during meiosis. Leitch and Bennett (2004) demonstrated that such homeologous chromosome pairing can cause restructuring and chromosome deletions that lead to reduction in DNA content. Indeed, the hybridization process induced DNA elimination in most of the hybrids evaluated in this study. However, in hybrid 2, neither DAP nor DNA content showed significant effects. The more stable behavior of this hybrid might be an indication that this genotype is better adapted to the hybridization process. This hybrid may therefore be selected for studies on chromosome duplication in an attempt to obtain fertile hexaploids for genetic breeding programs.

In hybrid 9, the DNA content increased during embryo development. This different behavior may be due to particular characteristics of the hybrid's parents, or abnormalities dur- 
ing the cell cycle as a result of hybridization. In a study of hybrids between pearl millet and oat, Ishii et al. (2010) observed that all the 7 pearl millet chromosomes were normally retained during embryogenesis. However, the addition of 1 chromosome, due to chromosome nondisjunction, was observed in $2.4 \%$ of the cells.

Recently, Ishii et al. (2010) demonstrated the action of the cohesin protein on chromosome elimination in interspecific hybrids between wheat and pearl millet. Chromosome abnormalities such as micronuclei, chromosome delay, non-disjunction, bridges, and chromosome breakage at the arms, among others, were frequent in hybrids in which cohesin degradation did not occur during the cell cycle.

DNA elimination during embryo development was higher in tetraploid hybrids than in the triploid hybrids. This variation was expected since the genotypes used as male parents (hexaploid hybrids) in these crosses were recently obtained by interspecific hybridization followed by chromosome duplication; therefore, the parents of these tetraploids were still in the process of genome stabilization. Thus, variation and/or elimination of DNA sequences were probably common events in these genotypes. According to Riddle and Birchler (2003), the new genome composition of hybrids may result in conflicts that lead to genetic and epigenetic reorganization. In cases in which the parental genomes are combined from successful fertilization, the elimination of specific DNA sequences occurs during the early stages of allopolyploidization (Liu et al., 1996; Feldman et al., 1997). A study on newly synthesized wheat allopolyploids has shown that hybrid formation was accompanied by extensive genome changes at the molecular level, including the rapid and non-random elimination of certain DNA sequences, as well as other types of genomic alterations (Ozkan et al., 2001).

Tetraploid hybrids 13 and 14 showed opposite trends to those seen in the other hybrids. There was an increase in the DNA content between 10 and 30 DAP, corresponding to 0.14 and $0.11 \mathrm{pg}$ in hybrids 13 and 14, respectively. According to Leitch and Bennett (2004), an expected response to allopolyploidization is the activation of transposons in the new genetic environment of the polyploid nucleus, which can cause an increase in DNA content. The precise effect of polyploidization on DNA content, i.e., an increase, a decrease, or no change, depends on the nature of the transposon and the mode and frequency of transposition.

DNA content estimates showed coefficients of variation lower than $2 \%$. Marie and Brown (1993) proposed coefficients of variation of 1 to $2 \%$ for high-quality results. Galbraith et al. (2002) defined a coefficient of variation of 5\% as an acceptance criterion for reliable DNA content estimates.

In addition to reductions in the DNA content identified from measurements conducted at different time points following pollination, another important result is the difference between the observed (30 DAP) and the expected value, as estimated from the average of parents. These results demonstrated that the hybrids $1,2,3,5,8$, and 9 were less sensitive to the decrease of the DNA content resulting from hybridization and/or polyploidization.

Several studies have demonstrated that natural selection for a reduced DNA content can be expected if this elimination contributes to genome stability and survival of the new polyploid formed (Leitch and Bennett, 2004). Rapid and non-random eliminations of sequences have been observed in Triticum-Aegilops polyploids, which play an important role in the differentiation between homeologous chromosomes, promoting the exclusive pairing between homologous chromosomes, as well as in the stabilization of the new polyploid formed (Levy and Feldman, 2004). Campos (2007) reported the phenomenon of genome instability during 
the development of triploid Napier grass/pearl millet embryos after interspecific hybridization. A reduction in nuclear DNA content of 4 to 6\% was observed after 30 DAP. The author also reported the frequent formation of micronuclei, an alteration normally related to the elimination of chromosomes and/or DNA sequences. These results agree with the present study in which alterations in DNA content were demonstrated by flow cytometry, suggesting the occurrence of genome sequence elimination after hybridization during the development of triploid and tetraploid Napier grass/pearl millet embryos. Further cytogenetic studies of the hybrids analyzed here should provide cytological evidence for the elimination of DNA sequences, such as micronuclei, delayed chromosomes in metaphase and anaphase, chromosome bridges, and chromosome fragments.

Flow cytometry analysis revealed the existence of ongoing genome instability in triploid and tetraploid hybrids between Napier grass and pearl millet, with this instability causing significant alterations in the DNA content of the hybrids. Among the 10 triploid hybrids analyzed, hybrids $1,2,3,5$, and 8 suffered less severe genomic alterations due to hybridization, and are therefore the most promising options for future use in Pennisetum spp breeding programs. The mean reduction in DNA content was high in the 5 tetraploid hybrids analyzed (about 30\%), suggesting that these hybrids are still in the process of stabilization after hybridization and that their use in Pennisetum spp breeding programs is currently not advised. This study also highlights the importance of flow cytometry as a tool to assist in the selection of genotypes for future use in breeding programs.

\section{ACKNOWLEDGMENTS}

Research supported by the following Brazilian agencies: Conselho Nacional de Desenvolvimento Científico e Tecnológico (CNPq), Fundação de Amparo à Pesquisa do Estado de Minas Gerais (FAPEMIG), and Associação para o Fomento à Pesquisa de Melhoramento de Forrageiras Tropicais (UNIPASTO).

\section{REFERENCES}

Abreu JC, Davide LC, Pereira AV and Barbosa S (2006). Mixoploidia em híbridos de capim-elefante x milheto tratados com agentes antimitóticos. Pesq. Agropec. Bras. 41: 629-1635.

Barbosa S, Davide LC, Pereira AV and Abreu JC (2007). Duplicação cromossômica de híbridos triploides de capimelefante e milheto. Bragantia 66: 365-372.

Brunken JN (1977). A systematic study of Pennisetum sect. Pennisetum (Gramineae). Am. J. Bot. 64: 161-176.

Campos JMS (2007). Obtenção de Híbridos Hexaploides e Análise Genômica em Pennisetum sp. por Citometria de Fluxo. Doctoral thesis. UFLA, Lavras.

Campos JMS, Davide LC, Salgado CC and Santos FC (2009a). In vitro induction of hexaploid plants from triploid hybrids of Pennisetum purpureum and Pennisetum glaucum. Plant Breed. 128: 101-104.

Campos JMS, Calderano CA, Pereira AV, Davide LC, et al. (2009b). Embriogênese somática em híbridos de Pennisetum sp. e avaliação de estabilidade genômica por citometria. Pesq. Agropec. Bras. 44: 38-44.

Dolezel J and Bartos J (2005). Plant DNA flow cytometry and estimation of nuclear genome size. Ann. Bot. 95: 99-110.

Feldman M, Liu B, Segal G, Abbo S, et al. (1997). Rapid elimination of low-copy DNA sequences in polyploid wheat: a possible mechanism for differentiation of homoeologous chromosomes. Genetics 147: 1381-1387.

Galbraith DW, Lambert GM, Macas J and Dolezel J (2002). Analysis of Nuclear DNA Content and Ploidy in Higher Plants. In: Current Protocols in Cytometry (Robinson JP, Darzynkiewicz Z, Dean PN and Dressler LG, eds.). John Wiley \& Sons, New York, 6-22.

Ishii T, Ueda T, Tanaka H and Tsujimoto H (2010). Chromosome elimination by wide hybridization between Triticeae or oat plant and pearl millet: pearl millet chromosome dynamics in hybrid embryo cells. Chromosome Res. 18: 821-831. 
Jones N and Pasakinskiené I (2005). Genome conflict in the gramineae. New Phytol. 165: 391-409.

Jones RN and Hegarty M (2009). Order out of chaos in the hybrid plant nucleus. Cytogenet. Genome Res. 126: 376-389.

Keller B and Feuillet C (2000). Colinearity and gene density in grass genomes. Trends Plant Sci. 5: 246-251.

Leitch IJ and Bennett MD (2004). Genome downsizing in polyploid plants. Biol. J. Linn. Soc. 82: 651-663.

Levy AA and Feldman M (2004). Genetic and epigenetic reprogramming of the wheat genome upon allopolyploidization. Biol. J. Linn. Soc. 82: 607-613.

Liu SC, Kowalski SP, Lan TH, Feldmann KA, et al. (1996). Genome-wide high-resolution mapping by recurrent intermating using Arabidopsis thaliana as a model. Genetics 142: 247-258.

Marie D and Brown SC (1993). A cytometric exercise in plant DNA histograms, with 2C values for 70 species. Biol. Cell 78: 41-51.

Martel E, De Nay D, Siljak-Yakovlev S, Brown S, et al. (1997). Genome size variation and basic chromosome number in pearl millet and fourteen related Pennisetum species. J. hered. 88: 139-143.

O'Kennedy MM, Burger JT and Botha FC (2004). Pearl millet transformation system using the positive selectable marker gene phosphomannose isomerase. Plant Cell Rep. 22: 684-690.

Ozkan H, Levy AA and Feldman M (2001). Allopolyploidy-induced rapid genome evolution in the wheat (AegilopsTriticum) group. Plant Cell 13: 1735-1747.

Pereira AV, Valle CB, Ferreira RP and Milles JW (2001). Melhoramento de Forrageiras Tropicais. In: Recursos Genéticos e Melhoramento de Plantas (Nass LL, Valois ACC, Melo IS and Valadares-Inglis MC, eds.). Fundação Mato Grosso, Cuiabá, 549-601.

Riddle NC and Birchler JA (2003). Effects of reunited diverged regulatory hierarchies in allopolyploids and species hybrids. Trends Genet. 19: 597-600.

SAS - Statistical Analysis System (2000). SAS/SAT 9.00. User's Guide. SAS Institute, Inc., Cary.

Steel RGD, Torrie JH and Dickey DA (1997). Principles and Procedures of Statistics: a Biometrical Approach. McGraw Hill Book, New York. 